\title{
A Critical Evaluation of Female Students' Inclination towards Higher Studies: A Case Study in the District of Loralai Balochistan
}

\author{
Muhabat Khan ${ }^{1}$, Nosheen Kanwal ${ }^{2}$, and Ghulam Ali Buriro ${ }^{3 *}$
}

\begin{abstract}
The aim of the study was to examine the inclination of female students towards higher studies in the Loralai District, Balochistan. The sample of the study was comprised of teachers $(N=100)$ and parents $(N=80)$ from the Loralai, District. The sample was selected through the purposive sampling technique. On behalf of the female students; a questionnaire was designed to make an elicit data from the sample. The collected data was analyzed through t-test. Consistent indicators for low inclination towards higher education were found to be cultural issues, opposition to co-education; low socio-economic status; size of the family, early marriages, distantly situated educational institutions and low parental educational background. Moreover, lack of parental involvement and their differential attitude towards sending their daughters to co-education institutions for higher studies was inversely correlated with female students' inclination towards higher studies. The implications for solutions were discussed.
\end{abstract}

Keywords: Inclination; Female Students; Higher Education; Balochistan.

\section{Introduction}

Islam, as a religion, is predominantly enculture in Pakistan in almost all facets of life. Religion and faith are, in fact, part of the Pakistanis' cultural heritage, and to remove religion from their educational ventures is to withdraw students of the advantage of a share of their birth-right (Hakim \& Aziz, 1998), especially when the quest of knowledge was enjoined by the Prophet (PBUH) as a sacred duty of every Muslim man or woman. Arguably, the right to formal education in the Western countries is a recent phenomenon, whereas interestingly in Islam, woman is not excluded from any field of social or economic activity from the early inception of the religion almost 1400 years ago. Rather, the Islamic conception of woman's place in society is that of an equal partner with man, from the spiritual as well as material point of view (Baloch, 2000). In addition, women are to be fairly treated as human beings and citizens of trained intelligence and informed understanding. In addition, females can play the biological role that nature has designed for them. Hence, women are not only to be the makers of the home, but also the stabilizers of the society. The situation of educated woman has also been endorsed by Education transforms lives (2013), which demonstrates that working women

\footnotetext{
Department of Education, University of Loralai, Balochistan, Pakistan. Department of Education, University of Loralai, Balochistan, Pakistan. Institute of English Language and Literature, University of Sindh, Jamshoro, Pakistan.
}

*)Corresponding Author.

Email: gaburiro@gmail.com 
in Pakistan with a high level of literacy skills earn 95\% more than women with weak or no literacy skills.

The association between religion and education is conventional; if the aim of education is the development of the whole individual, of a wellrounded, balanced personality, realizing his/her place in the order of creation, perceiving his/her purpose in life and actively co-operating in the life of the community; it is obvious that it cannot stop with the development of his/her intellectual powers and leave to chance his/her moral and spiritual growth and development. However, findings of the Global Education Monitoring Report indicate that " $48 \%$ of the poorest girls aged 5-16 are enrolled in school, compared to $68 \%$ of the poorest boys the same age" (Girls' Education in Pakistan, 2016; p. 1) which is contrary to the religious obligations. Although, it has also been stressed upon that "Pakistan has the second highest number of children out of school in the world" (p.2).

The limitless possibilities of positive development according to individual predisposition, which are open to men, are equally available to women. It must be remembered that seclusion of women is not enjoined by Islam. Women are permitted to go out and transact their affairs in order to meet the usual requirements of their life, just as men do. In the current age, the parents want their daughters to be educated because they wish their girls to grow up in the best traditions of Islamic womanhood and this demand can preferably be met in same sex schools. Loralai is a far flung Pashtun area of Balochistan, consisting of about 0.5 million people having special traditions, norms and values in a small city. The main occupation of men is farming and some sort of business while females are confined to their household work. The literacy rate is quite appreciable among males but very much deplorable among the females due to certain addressable issues. The foremost one is 'Purdha' (veil), the people of this region do not allow their females to freely move in the city. They are not in favor of their daughters attaining higher education when they pass the matriculation examination which is equivalent to ordinary level (Malik, \& Nawaz, 2016).

Starkey \& Kleir (2000), revealed that the attitude of parents toward education greatly impacts their contribution in educational matters. Indeed, parents association in their children education is extremely significant in the academic performance when they support their kids at home and moreover, helping them in their home assignments. Rao (1991) stated that the result of parents' contribution is very much fruitful and significant as children being encouraged if home and school both keep eye to eye in the process of learning. According to the study of Kafas (2009) parental carelessness can be a failure when a parent does not meet a child's basic needs such as physiological and psychological that results in serious impairment of the child's development and health. Chrispell \& River (2001) described that it's the core responsibility of parents to care about their children's' emotional, psychological, spiritual, educational and physical needs. Hountenvilli \& Conway (2008) also elaborated on the impact of parental involvement on the academic 
achievement and stated that the interest of parents in their kids' education has positive effect on their outcomes. Furthermore, Rehmani (2006) reports "low quality education has been the low percentage of expenditure on education" (p. 500).

Obsorne (2003) concluded that the attitude of students towards higher education can be like feelings, values and beliefs which are followed with clear understanding. In the context of several research studies, the purpose of higher education is to develop and increase a positive attitude towards higher studies regardless of individual differences (Arisoy, 2007; Azizoglu \& Cetin, 2009). Newhouse (1990) demonstrated that attitude towards studies can be a very important factor which molds human behavior and intention. In the same vein, Koran \& Koran (1984) emphasized that individual differences, too, play a pivotal role in students' learning process. Apart from undermining female literacy, co-education is also a crucial issue; parents hesitate to admit their daughters in the same school, college and university where boys are studying (Chaudhry, 2007). Indeed, co-education is the education of boys and girls together in the same classes of a school, admission to the school being secured by pupils of both genders on merit, equal terms, opportunities and access to curricular and co-curricular activities. The role of teachers in this regard is crucial; Khan (2012) argues that "a change occurs when teachers are able as well as motivated to try new things and to reflect on the consequences" ( $p$. 43). There has been objection to co-education at school, college or university level except some areas of Balochistan, especially in the district of Loralai. Although, co-education institutions prepare students in handling the needs of the society and such type of education can be an essential factor in career development as well. Moreover, students are exposed to each other, resulting good mutual understanding for the career aspect. The spirit of competition is developed between male and female students which take places in various fields of study.

The ever serious issue which adversely affects girls' education is their early marriages. In rural areas of the country, it is a very common practice to get their daughters married in early age; therefore, their formal education is restrained. According to the study of UNICEF's (2001) the acceptance, consequences and causes of early marriage reinforces the necessity for more research and action to contain the harmful consequences of this practice. In the said district, the Pashtun tribe keeps the same practice; their daughters get married in their teenage which discontinues their education. Resultantly, women have to endure a weaker status in society. Indeed, girls have very limited control over their future decisions because within such societies, they have to overcome multiple hurdles before they can understand their right of education.

Benn (2005) contributed his views that the government commitment and leadership are known to be critical to ensure, so that more girls get into school because there are many examples which shows how good reforms and policies on girls' education made slight difference at school level. They are 
not prioritized by local or central officials, or since they are not accompanied by additional resources. Moreover, it is also the responsibility of politicians to ensure these policies and translate them into action for providing better opportunities for girls' education. Therefore, leadership is very essential within communities and schools because teachers can be the promoters for encouraging girls to go to school. Similarly, this impact increases the number of female teachers' recruitment in the profession (Benn, 2005).

Blake (1989) stated that families with more children dilute their cultural, economic and other resources as compared to those families with fewer children. In large families, Parents invest less money, emotional energy, time and attention on each child. Maralani (2004) analyzed three elements related to the impact of sibling size on their educational accomplishment. The first one is the effect of sibling numbers on educational achievement are subjected to the level of society and its development and access to schooling. The second element is, dissimilar to assumption of weakening hypothesis; eldest child in a large family may provide more resources and time for schooling through allocation the household responsibilities and other labor market work. The last one, the effects are also helpless to change for different macro-level factors, such as migration and urbanization trends in the community, educational opportunities and costs in the state and reproductive behavior and gender roles of society.

Saeed (1990) analyzed in his research that mostly girls are confined into houses, so as to work with their mothers in household at the early years. Therefore, they are not admitted in schools and even if they are enrolled, their attendance is quite thin which causes a high rate of dropout. In this context Khalid (1996) stated that in rural areas of Pakistan, societies are male dominant. Thus, men are the head of the families and the decision makers; consequently, they give less importance to girls' education. Parents are worried that if their daughters are educated, they would certainly demand their rights; for instance, educated husband and equal rights with their brothers. Lockheed \& Jamison (1979) shared their views about female education, stated that in many societies parents decide that education is not meaningful for girls who will eventually move into their in-laws. Thus the prospective advantages due to literacy will be accorded to the families of their son-in-law rather than their own.

Burney \& Irfan (1991) concluded that culture is not the only factor determining the girls' education but parental attributes and their socioeconomic position are also of pivotal importance for the female schooling. Moreover, the educational level of parents also contributes its role in female education because highly qualified parents consider education as the ever costly ornaments for their daughters. Graaf (1986) presented the indirect approach to seize the effects of parents' education regarding the educational accomplishment of their children. He stressed upon the three background characteristics: the education of father and mother, occupation and their socioeconomic status. Sawada \& Lokshin (2001) stated that parents' educational 
level is related to the children's educational attainments in Pakistan because educated parents emphasize on teaching environment at ho,me.

Mansory (2007) stated that school distance is another serious obstacle for female education in remote and rural areas. Therefore, long distances discourage females from being educated for two reasons. The first one is the length of time and the second is the physical energy which is needed to cover the distance with empty stomach. Ainsworth (2005) analyzed that close vicinity to the institution has been a positive effect for girls' education. Parents are worried about the safety of their daughters when they send them to the institutions far away from their residences.

\section{Method}

The present study attempted to explore the inclination of female students towards higher studies in the Loralai District. The nature of the study was cross sectional survey design because of the time availability.

\section{Sample of the Study}

The population of the study was included of all school teachers and parents of Loralai District. Thus, the population was large and scattered, therefore purposive sampling design was adopted for the study to elicit data regarding female students' inclination towards higher studies.

\section{Respondents}

The respondents of the study comprised of 100 teachers (60 male and 40 female) from 10 different schools and 80 parents (50 fathers and 30 mothers) from Loralai District.

\section{Instruments}

The research instruments contained of two questionnaires which were translated into both Pashto and Urdu languages for their comprehensibility. Both questionnaires were comprised of three sections and each part was consisted on 20 items. The three sections of the questionnaire for teachers focused on:

i) Female students' knowledge of daily lessons.

ii) Ability of female students to relate to skills.

iii) Desirous of using intellectual promise for future endeavors.

The second questionnaire was distributed individually to parents at their residence. The three sections of the questionnaire reflected on:

i) The parents' satisfaction with their daughters' education.

ii) Parents' concerns regarding their daughters' current educational level.

iii) Parents interest in their daughters' higher studies. 
On the completion of the survey, parents were debriefed about the purpose of the research and also inquired about their specific responses for further elaboration.

\section{Data Collection}

The researcher distributed questionnaires among the teachers in selected schools situated in the main city of District Loralai. However, the contact numbers of parents were requested from the headmasters/headmistresses of the same schools. They cooperated in providing more than 100 parents' telephone numbers and addresses. The researcher personally met 80 parents and requested to fill the questionnaires. For the ease of some parents the questionnaire was translated into their local language (Pashto).

\section{Data Analysis}

The numerical data was obtained from the responses of the questionnaire by using a Likert scale. The collected data was analyzed through statistical technique i.e. t-test. The study hypothesized:

\subsection{Hypothesis: 1}

There is no significant difference between the opinion of male and female teachers about the inclination of female students towards higher education in Loralai District.

\subsection{Analysis of the Problem}

1. $\mathrm{H}_{\mathrm{O}}: \mu_{1}=\mu_{2}, 2 . \mathrm{H}_{1}: \mu_{1} \neq \mu_{2}, 3 . \alpha: 0.05$,

4. Test Statistics: $\mathrm{t}-$ test $=1.75$

Result: The null hypothesis is rejected if the computed $t \geq 1.99$.

Table 1. Showing the result for Hypothesis 1

\begin{tabular}{|c|c|c|c|c|c|c|}
\hline Group & Sample & Mean & S.D. & $\mathrm{T}$ & Probability & Df \\
\hline Male & 60 & 84.26 & 54.40 & & & \\
\hline $\begin{array}{l}\text { Teachers } \\
\text { Female } \\
\text { Teachers }\end{array}$ & 40 & 77.25 & 57.45 & 1.75 & 0.05 & 98 \\
\hline
\end{tabular}

\subsection{Results}

According to table $\mathrm{t}$, it is found that the tabulated value of $\mathrm{t}=1.98$ with $\mathrm{df}=$ 98 at $\alpha=0.05$ is greater than the computed value of $t=1.75$. Hence, the null hypothesis is upheld and it is concluded that there is no significant difference between the opinion of male and female teachers about the inclination of girls' students towards higher education in Loralai, District. From the assessment of the $\mathrm{t}$-table it is found that teachers have positive attitude for female education. 


\subsection{Hypothesis: 2}

There is no significant difference between the opinion of Fathers and Mothers about the inclination of their daughters towards higher education in Loralai District.

\subsection{Analysis of the Problem}

1. $\mathrm{H}_{\mathrm{O}}: \mu_{1}=\mu_{2}, 2 . \mathrm{H}_{1}: \mu_{1} \neq \mu_{2}, 3 . \alpha: 0.05,4$. Test Statistics: $\mathrm{t}-$ test $=2.23$.

The null hypothesis would be rejected if the computed $\mathrm{t} \geq 1.98$.

Table 2. Showing the result for Hypothesis 2

$\begin{array}{lllllll}\text { Group } & \text { Sample } & \text { Mean } & \text { S.D. } & \text { T } & \text { Probability } & \text { Df } \\ \text { Fathers } & 50 & 91.60 & 47.50 & & & \\ \text { Mothers } & 30 & 82.73 & 50.40 & 2.23 & 0.05 & 78\end{array}$

\subsection{Results}

According to t-table, it is found that the tabulated value of $\mathrm{t}=1.99$ with $\mathrm{df}=$ 78 at $\alpha=0.05$ is less than the computed value of $t=2.23$. Hence, the null hypothesis is rejected and it is concluded that there is a significant difference between the opinions of parents about the inclination of girls' students towards higher education in Loralai District. From the assessment of the table, it is deduced that fathers were found more concerned about their daughters' higher education as they showed slightly positive attitude regarding their daughters' education, but conversely, mothers indicated a negative attitude to send their daughters to college and university. Hence, showing an imbalance generated by females themselves.

\section{Discussion}

This study is one of the very few studies that have explored teachers and parents' views on the inclination of female students for higher studies. The purposive sampling method was used to assess parents' views on female education in general and higher education in particular followed by debriefing of the parents. The study presents interesting results on the basis of both hypotheses: The findings concerning both the male and female teachers are of particular significance as it demonstrated positive trend towards female students' inclination for higher education. Based on their daily observation as well as summative assessment, teachers' contribution in this domain reports crucial details. Both male and female teachers were appreciative of their students' interest in higher education. Similarly, the findings obtained by the parents provided useful information especially about the difference between parents' opinion. Initially a focus group was arranged as the research aimed to use mixed methods for more a holistic view of the current situation, but due to constraint of time the focus group could not be arranged. However, the parents were debriefed once the questionnaires were filled in. Debriefing was 
pertinent in providing qualitative account of their views about their daughters' higher education.

However, the findings obtained from parents, present an interesting contrast; fathers had more positive view of their daughters' inclination whereas mothers were more apprehensive of their daughters' further education. Females seemed to have succumbed to their fate and have adopted a more submissive conventional role. During the debriefing phase mothers expressed their concern that due to observing cultural and religious 'Purdha' and other traditional rituals, they cannot send their daughters for higher studies. Halai (2003) acknowledges the crucial role played by contextual factors to fully comprehend the implementation of any measure for improvement. Though, some of the parents admitted that higher education is as much compulsory for their daughters as for their sons, but the fact is, their relatives, neighbors and other people in the surroundings passing sarcastic and negative remarks about their daughters which create hurdles in their marriages and other social relations. Indeed, girls are negatively treated in their society, in brief; people are then reluctant to marry their daughters if they get higher education elsewhere away from their homes. Mothers were found more worried about the prestige of their daughters.

It was found that the involvement of parents in their children's education was unsatisfactory, because of their personal insufficient education. In fact, they have no communication with teachers for a longer period since they have admitted their children in those institutions. They do not help in the homework, assignment and other projects with their children. The findings of the study are significant in highlighting the conventional roles played by females are restricting them from offering supporting their daughters in terms of their higher education. Hence it emphasizes that parents', especially mothers', role is more crucial in upgrading the current situation in the remote areas.

One of the most controversial issues for not sending their daughters to universities was co-education. They were found completely against studying both the gender in the same time, same institution and in the same class. In response to item 6 in the questionnaire on co-education, at middle and senior levels, $80 \%$ parents both mothers and fathers expressed their concern and did not approve of it. However, their opinion about co-education at the primary level (item 3) was found a bit positive.

Moreover, the responses of both male and female teachers were found in favor of co-education. They strongly recommended that it does not harm the female students' prestige and never dilute their place in the society if they are educated in co-education system. It was revealed from the opinion of parents and teachers that mostly girls get engaged for marriages during their school period. Consistent with Gender Inequality Index (2016) the study validated that female students' education is affected due to having a number of domestic responsibilities. Since, they have to manage the household tasks to reduce pressure from their in-laws. Moreover, it was found that after early marriages, 
the birth of children is another obstacle for females to continue higher education.

It was found from the responses that the socio-economic status of the parents also affects the educational momentum of the children. In the point of view of the respondents, the number of siblings was another factor for the low proportion of education. It was found to be difficult for single bread earner to pay the expenses of 5 or 6 children from one salary or minor business. Therefore, some parents were found in favor of their daughters' higher education but due to low income, their children, especially girls are out of schools and colleges. They showed a great interest to admit their kids in educational institutions whenever their financial position becomes strong.

\section{Recommendations}

On the basis of the above discussion, it is strongly recommended that the government and non-government organizations should take serious interest in educating females in the rural areas of Pakistan in general and Loralai District, Balochistan in particular. It is widely accepted that $70 \%$ population of Pakistan dwell in the rural areas.

Since the decision making rests with parents so the provision of samesex schooling will enhance female enrollment for higher studies. Parents may also be convinced and informed through print and electronic media about the significance of girls' education.

Furthermore, Parent-teacher meetings should be conducted in which parents' participation must be ensured. Similarly, early marriages should be discouraged on medical grounds and more attention has to be paid on their daughters' education.

The government should make the scholarship policies as much flexible as possible for the low socio-economic families and other deserving candidates so that their education will not suffer due to poverty. Recommendations are made to draw the attention of the concerned authorities to solve these issues to improve female higher education.

\section{References}

Ainsworth, M. (2005). Socioeconomic Determinants of Fertility in SubSaharan Africa: A Summary of the Findings of a World Bank Research Project. Washington D.C.: The World Bank

Arısoy, N. (2007). Examining 8th grade students' perception of learning environment of science classrooms in relation to motivational beliefs and attitudes. Unpublished Theses in Middle East Technical University, Ankara, Turkey. Attainment in the Netherlands. Sociology of Education, 59(10), 237-246.

Azizoğlu, N. \& Çetin, G. (2009). The effect of learning style on middle schools students' motivation and attitudes towards science, and the relationships among these variables. Kastamonu Education Journal, 17(1), 171-182. 
Hakim, A. \& Aziz, A. (1998). Socio-Cultural, Religious, and Political Aspects of the Status of Women in Pakistan. Journal of Pakistan Development Review, 37(4) 727-746.

Blake, J. (1985). Number of siblings and educational mobility. American Sociological Review, 50, 84-94

Burney N. A. \& M. Irfan. 1991. Parental characteristics, supply of schools, and child school- enrolment in Pakistan. The Pakistan development Review, 30(1): 21

Chrispell, J. H. \& River, F. (2001). Engaging Latin Families for Student success: How parent Education can reshape parents sense of place in the education of their children. Peabody Journal of education 76(2) 119-169.

Chaudhry, S. I. (2007). Gender inequality in Education and economic Growth: Case study of Pakistan. Journal of women's Concerns in International relations, 60(4) 81-91.

De Graaf, P., M. (1986). The impact of financial and cultural resources on educational attainment in the Netherlands. Sociology of Education, 59(10), 237-246.

Education Transforms Lives (2013). Education for All Global Monitoring Report, UNESCO, http://unesdoc.unesco.org/images/0022/002231/223115E.pdf

Girls' Education in Pakistan. (2016). Global Education Monitoring Report. Retrieved on $2^{\text {nd }} \quad$ January 8, 2018 from http://aserpakistan.org/document/aser/Pakistan_Fact_Sheet2016.pdf

Halai, A., (2003). Planning impact research: issues and dilemmas. In A. Halai and J. Rarieya (Eds.), Impact: Making a Difference; proceedings of an International Conference held at AKU-IED, Karachi, Pakistan, 376-379.

Hountenvilli, A. J. \& Conway, S. (2008, May 28). Parental Involvement Strongly Impact Student Achievement. Science Daily. Pp 28.

Kafas, P. (2009). Child Neglect. A Review; The Internet Journal of Forensic Science, 4(1), 1-5.

Khalid, H.S. (1996). 'Female Teachers' and Girls' Access to Primary Schools in rural Pakistan: A Case Study" (PhD thesis). Retrieved from https://aus.libguides.com/apa/apa-theses

Khan, M. (2012). Teachers learning from professional development program for primary school teachers and translating their new learning into actions in primary schools in the context of Chitral Pakistan. International Journal of Academic Research in Economics and Management Sciences, 1(2), 4152

Kirkwood, J. (2007). Igniting the Entrepreneurial Spirit: Is the Role Parents Play Gendered? International Journal of Entrepreneurial Behavior and Research, 13(1), 39-59

Koran, M. L., \& Koran, J. J. (1984). Aptitude- treatment interaction research in science education. Journal of Research in Science Teaching 21(8), $793-$ 808 
Malik, Z. \& Nawaz. A. (2016). Female Education Problems in Pakistan. Journal of Educational Science and Research (JESR) 6(1), 1-4.

Mansory, A. (2007), Drop out Study in Basic Education Level of Schools in Afghanistan, Kabul: Swedish committee for Afghanistan. www.nzdl.org/gsdlmod

Mare, R., D. \& Maralani, V. (2006). The intergenerational effects of changes in women's educational attainments. University of California, Los Angeles.

Nabī Baknhshu Khhānu Balocu, 1. (2000). Education based on Islamic values: imperative and implications. Jamshoro: Pakistan Study Centre University of Sindh. https://catalog.hathitrust.org/Record/003784075/Cite

Newhouse, N. (1990). Implication of attitudes and behavior research for environmental conservation. The Journal of Environmental Education, 22(1), 26-32

Osborne, J. (2003). Attitudes towards science: a review of the literature and its implications, International Journal of Science Education, 25(9), 10491079.

Parveen, S. (2008). Female Education and National Development: As Viewed By Women Activists and Advocates. Bulletin of Education \& Research 30(1), 33-41. Retrieved from http://pu.edu.pk/images/journal/ier/currentissue_pdf/7_Saleha\%20Parveen $\% 20$ Article_BER.pdf

Rehmani, A. (2006). Teacher education in Pakistan with particular reference to teachers' conceptions of teaching. Quality in education: Teaching and leadership in challenging times, 20, 495-524.

Rao, N., S. (1991). Counseling and Guidance. New Delhi, McGrawHill Research group, World Bank, Washington D.C.

Saeed, A. (1990), Structural Issues in Women Development in Pakistan, UNICIEF; Islamabad, pp.27-35.

Sawada, Y. \& M. Lokshin. (2001). Household schooling decisions in Rural Pakistan. Policy school- enrolment in Pakistan. The Pakistan development Review, 30(1): 21

Starkey, P. \& Kleir, A. (2000). Fostering Parental Support for Children's Mathematical Development: An intervention with Head Start Families Early and Development. 11(5) 659-680.

UNICEF (2001). "Life after Early Marriage". Child Marriages Must Stop. Web Feature. Retrieved from www.unicef.org/notworthy/earlymarriage/ index.htm1.Working Research Paper 2541. Poverty and Human Resources Development 